\title{
Reflections of relationship in Information and Communication Technology by Small and Medium Enterprises of Pottery Industry in Jalisco, Mexico
}

\author{
Juan Carlos González-Castolo \\ Universidad de Guadalajara, México \\ jcgcastolo@hotmail.com \\ Silvia Ramos-Cabral \\ Universidad de Guadalajara, México \\ silviarc@valles.udg.mx
}

\section{Resumen}

En el presente artículo se expone una reflexión referente a la utilización de las Tecnologías de Información y Comunicación por parte de las Pequeñas y Medianas Empresas de la Industria Alfarera del estado de Jalisco, con el fin de potenciar el esquema de negocio. También se presenta un método formal para describir las particulares que se deben atender en el desarrollo del portal WEB de modo que cubra el proceso de compra-venta adecuadamente. Estos argumentos podrían extenderse al análisis del comercio de otros productos como verduras, frutas, dulces, etc. Finalmente se hace una propuesta de las características de dicho portal con el cual se pueden concretar los puntos discutidos a lo largo del presente trabajo.

Palabras clave: Pyme, TIC, Alfarera.

\section{Abstract}

This article presents a reflection concerning the use of the Information and Communication Technologies by Small and Medium-sized Enterprises of the Pottery Industry in the State of Jalisco, in order to enhance the business scheme. It also presents a formal method to describe the particularities that should assist in the development of the WEB portal so that covers the process of buying and selling properly. These arguments could be extended to 
the analysis of trade in other products such as vegetables, fruits, sweets, etc. Finally a proposal of the features of the portal is made with which you can specify points discussed throughout this paper.

Key Words: SMEs, ICT, pottery.

Fecha recepción: Enero $2015 \quad$ Fecha aceptación: Junio 2016

\section{Introduction}

Currently, the use of Information and Communication Technologies (ICT) is massive and this fact is more pronounced in young people, (Calvo Marín \& Ospina Ospina, 2014). Given that the concept of ICT is not always well interpreted and since it is mentioned in this work, then a first explanation is essential. Using an elementary reasoning, it is known that $I C T$ are used by everyone if we affirm that this concept is regarding to the use of mass storage media, handling and data transfer, (Belloch, 2012), (Tello, 2007). Companies are entities formed with human elements, among other things. These elements are organized in order to offer goods or services that could give profits to them. Being as ICT are inherent to people, then is common to say that ICT are used by all companies in their administration. A company with a small number of employees is classified as a Small and Medium Enterprises and it is identified with the acronym SME (Saavedra García \& Tapia Sánchez, 2013), (INEGI, 2009). The pottery industries of the Jalisco state is a SME that hereafter be referred as SMEpott. It is known that the basic aspiration of all SMEpott is expand its market participation. To achieve this goal, financial resources are needed. The growth industry has a direct correlation with organizational strengthening. It is also undeniable that any SMEpott is composed by: a) possessions, b) people and c) techniques, (Montoya del Corte, Martínez García, \& Somohano Rodríguez, 2013). Returning to the idea, it is known that financial resources can come from external and / or internal sources. The internal source is referred to enterprise profits, (Llamas Aréchiga, González Aboytia, Vásquez Duarte, Siari Valenzuela, Valenzuela Hernández, \& Silva Hernández, 2014), (Reyes Nodhal, Alvarado Castellanos, \& Marcelo Guevara, 2013). In this case the SMEpott has a 
growth strong because it has strengthened its parts with $(c, b, a)$ order that means: techniques, people and possessions. This is noted because c) there in refining the management and / or production to maximize profits, b) people skills and / or knowledge have been increased because company has made a sustained selling, a) it is possible to have an increase of material possessions as enlarge spaces and / or acquire equipment that help to give responsiveness to demand due to increased sales. Of course that the parts of the SMEpott are intrinsically linked and therefore it strengthening only is accentuated and not exclusive. When financial resources come from an external source, the SMEpott has a speculative growth. An example of this funding is given by bank loans, (Briozzo, Vigier, Castillo, Pesce, \& Speroni, 2016), (Algieri, 2007), (Aguilera Enríquez, González Adame, \& Rodríguez Camacho, 2011). The growth order of the company is $(a, b, c)$. For example: a) machinery is purchased, b) workers are trained, c) policies are changed. While it is important that all parts of the SMEpott grow, it is desirable to do this with strong growth or failing with combination of external source, since the mastery of technique is basic to resist and respond to new financial commitments generated by monetary loans (Aguilera Enríquez, González Adame, \& Rodríguez Camacho, 2011).

In view of the above, the interest-arousing question is: How to increase profits to achieve steady growth? The answer raises new questions: 1) How to acquire cheaper inputs?, 2) How to reduce operating expenses? and 3) How to sell more?

Before addressing the questions, it is necessary to delve into ICT concept. So, ICT are related to the human history. These can be classified into physical ICT as: newspapers, magazines and; signal ICT such as: radio, television. Signal ICT includes digital ICT, which refers to use of networks, terminals and services (Tello, 2007). In general, within common slang, ICT concept is linked to the idea of digital computers management and that shows that digital ICT are named as ICT. Accordingly with this and in order to avoid a long dissertation, digital ICT will be called as ICT simply. 
Currently the use of ICT motivates a massive number of people because it facilitates to have the communication channels open and besides that digital equipment's are affordable. This is evident if it is observed that services, networks and equipment are manifested for example: in Facebook, Internet and smartphones, respectively, (Luna Huertas, Ruiz del Castillo, \& López Jiménez, 2012), (Hernández Gutiérrez \& Reta Martínez, 2011), (Gómez Sánchez \& Dorantes Escamilla, 2006). So it can be said that ICT are resources of social relations of daily life.

Having regards to the ICT, the three outstanding questions and possible answers are retaken.

1) How to acquire cheaper inputs?

a) Buying more inputs from the same supplier

b) Looking new suppliers

2) How to reduce operating expenses?

a) Optimizing tasks and / or staff reduction and / or current expenditure

b) Making alliances and / or agreements with other entities including other SMEpotts

3) How to sell more?
a) Improving the way to offer
b) Cutting prices
c) Offering up new products

ICT involves most responses directly and / or indirectly. For instance, if question 1 and answer $a$ were attended, than would be necessary increase the production to consume the supplies purchased, which will force to attend the 3th question and answer $b$ previously. It could be achieved keeping prices above production costs, but that consequently limits the profits (Alburquerque, 2004), (Mochón, 2006). The question 3 and answer $c$ seem to be viable if it is guaranteed that demand exists. Regard answer $a$ to question 3 involve enable, enhance and / or promote the use of ICT in SMEpott as an option that deserves attention because its massive and affordable use, as stated above (Gómez Sánchez \& Dorantes Escamilla, 2006), (Aguilera Enríquez, González Adame, \& Rodríguez Camacho, 2011). 
According to (Hernández Gutiérrez \& Reta Martínez, 2011) to achieve better way to bid (answer a of question 3) the site should address some basic requirements:

- It must have efficient speed access,

- It must be visually appeal,

- It must be easy to navigate,

- It must be clear and simple the buying and selling process,

- It must be cross-platform, accessible from a browser and / or app,

- It must have feedback function, among others.

No less important is to attend desirable requirements of SMEpott's site, for example:

- It must be quick and easy to update,

- It must be quick and easy to modify,

- It must be economical keep the site,

- It must be reliable always keep online,

- It must be portable.

Assuming that the site reaches consumers of the SMEpott's products, than is necessary to address the issue concerning to effective transportation. It is recommendable to have especially careful with shipping costs in order to make the best transaction. Shipping is an important factor (Anaya Tejero, 2015) because it must be remembered that SMEpott products are heavy and / or bulky generally.

Jalisco has an important number of industries that they have products with export characteristics, (Jalisco, 2016), Figure 1. Industries mentioned do not use any web portal specialized in ceramics to market yet. In general, they use the traditional method, where customers physically need attend to buy the products. Among they could be find that someone uses TIC but with limitations for example using email or publicity in the WEB. 


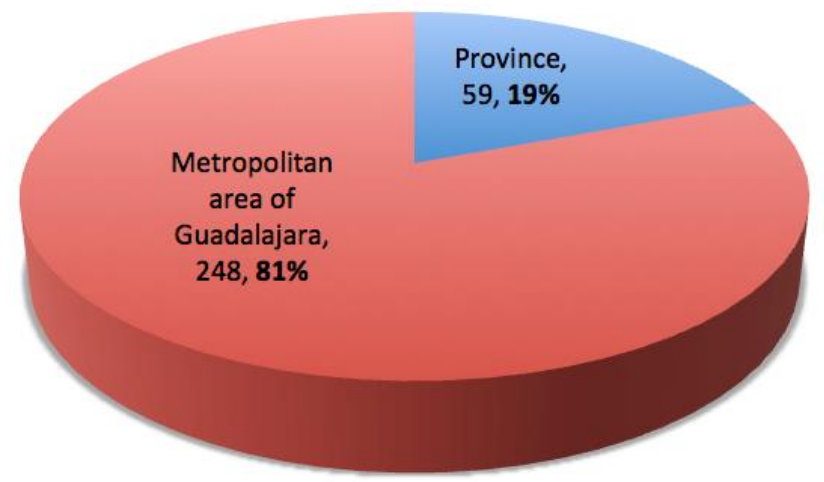

Figure 1. Pottery industries in Jalisco with products that could export. (Jalisco, 2016)

In the WEB exist different places to commercialize pottery and / or freelance but neither of them has development and support in Mexico. These places are known as Marketplaces and some of them are: ezebee, craftual, artesanum, dawanda, artesanio, etc. The business concept is suitable for the different countries. The advantage in Jalisco is that more of $80 \%$ of pottery industries are in Metropolitan area of Guadalajara and this could help to organize people and impulse some local polity of development.

\section{Background}

Concept map is a tool of knowledge representation and it resembles a bi-graph where each concept and arc label is a node. Arcs are used to relate concepts. The concept must be connected with arc labels and arc labels must be connected with concepts. The tree of concepts starts and ends with concepts where they are organized from up to down. The distribution of conceptual map follows a logical link. Figure 2 shows that the concept $A * B$ is justified only if concepts $A, B$ are given previously and is reading as if $A$ and $B$ then $A * B$. Concepts $A, B$ and $C$ justify a concept that is explained by two background and this is interpreted as if $A$ and $B$ or $C$ then $(A * B)+T 1 C$.

Summarizing, if a concept has two or more input arcs then is interpreted that the concept is grounded with two or more options. If a label arc has two or more input arcs then is interpreted that the previous concepts are necessary to justify the next output concept (González García, 2008). 
Figure 2. Concepts maps logic.

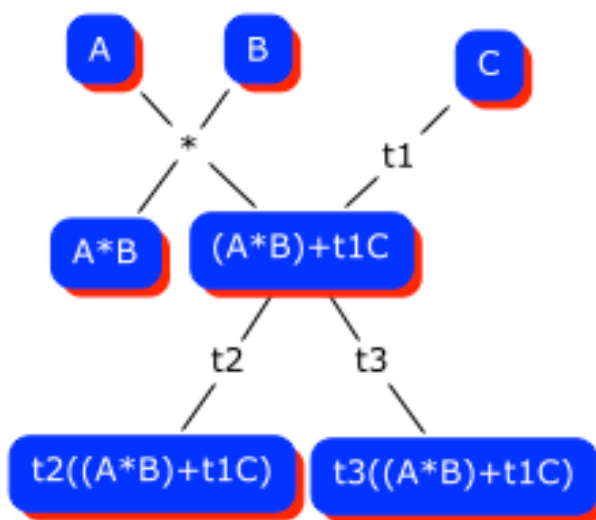

Source: Own source.

\section{Analysis}

Let $A$ be the label of SMEpott, then a group of all SMEpott is represented as,

$$
\text { SMEpotts : } A_{i} \mid i \quad\{1, \ldots, g\}
$$

where $g$ is the amount of SMEpott.

Let $P$ be a product of SMEpott ( $P A$ ), then different products of different $A$ are represented as,

$$
\text { Product }_{j}: P_{j} \mid j \quad\left\{1, \ldots, n_{i}\right\} ; i \quad\{i, \ldots, g\}
$$

Whether $O$ are objects belonging to $P$, then the different objects are represented as,

$$
\text { Object }_{k}: O_{k} \mid k \quad\left\{1, \ldots, m_{j}\right\} ; j \quad\{1, \ldots, n\}
$$

A specific object $k$ belonging to a specific product $j$ in a specific company $i$ is represented as,

$$
O_{i, j, k} \mid i \quad\{1, \ldots, g\} ; j \quad\left\{1, \ldots, n_{i}\right\} ; k \quad\left\{1, \ldots, m_{j}\right\}
$$


Figure 3. Tree list of entities in SMEpott.
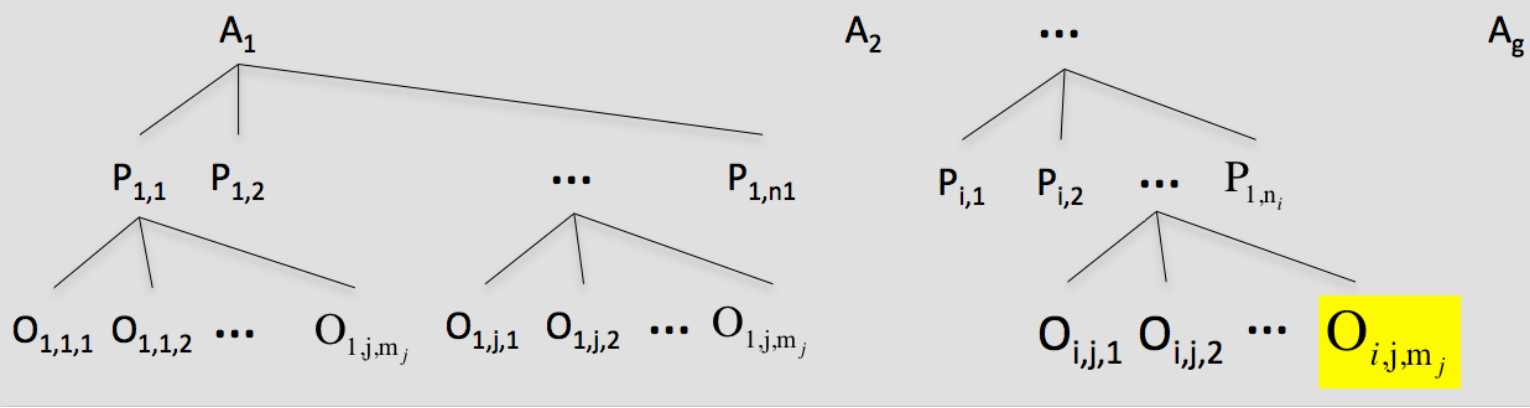

Source: Own source.

A buyer $r$, where $q$ is the number of buyers, is represented as

$C_{r} \mid r \quad\{1, \ldots, q\}$

Sale Moment (SM) is defined as the length of time that a potential buyer $C_{r}$ is watching and evaluating or purchasing and post-evaluating the acquisitions of product $j$ in SMEpott $i$ ( $\left.S M_{P_{i, j}, C_{r}}\right)$.

Since the products are grouped by similarity then the $S M$ can be referenced in terms of objects $(O)$ such that $M V_{O_{i, j, k}, C_{r}}$ where $k \quad\left\{1, \ldots, m_{j}\right\}$ and $m_{j}$ is the number of objects in the group. Then, the $S M$ is extinguished when $C$ bought and post-assessed or stops seeing and non-evaluates the P acquisition (Stanton, Etzel, \& Walker, 2007). The $|S M|$ has a numerical result and is nonzero when a purchase exists and therefore it is matched with the number of objects sold in an event.

$$
\begin{aligned}
& \left|M V_{O_{i, j, k}, C}\right|=0 \Rightarrow\left(O_{k} \notin C\right) \wedge\left(O_{k} \in \text { PymeAlf }\right) \mid k \in\{1, \ldots, m\} \\
& \left|M V_{O_{i, j, k}, C}\right|=k \Rightarrow\left(O_{k} \in C\right) \wedge\left(O_{k} \notin \text { PymeAlf }\right)
\end{aligned}
$$

The number of $S M$ is according with the number of $C$ that are seeing and evaluating or purchasing and post-evaluating each $P$. Then the $S M$ can be occur in parallel if more than one $C$ are coinciding with same $P$ at same time,

$$
M V_{P_{i, j}, C_{1}} / / M V_{P_{i, j}, C_{2}} / / \ldots / / M V_{P_{i, j}, C_{q}} \mid c_{1} \quad c_{2} \quad \ldots \quad c_{q}
$$


Also, one $C$ can generate $S M$ in parallel if different $P$ are attended at the same event,

$M V_{P_{i, j}, C} / / M V_{P_{i, j}, C} / / \ldots / / M V_{P_{i, j}, C} \mid\left(\begin{array}{llll}j_{1} & j_{2} & \ldots & j_{i}\end{array}\right)\left(j_{1}, j_{2}, \ldots, j_{i} \quad\{1, \ldots, n\}\right)$

Exist a conflict of offer if SM has a purchase and post-evaluation with more than one $\mathrm{C}$ at the same time and the number $\left({ }^{m_{j}}\right)$ is less than demand (Mochón, 2006).

$\left|M V_{O_{i, j, k}, C_{1}}\right|+\left|M V_{O_{i, j, k}, c_{2}}\right|+\ldots+\left|M V_{O_{i, j, k}, C_{q}}\right|>m_{j} \mid c_{1} \quad c_{2} \quad \ldots \quad c_{q} ; k_{1}, k_{2}, \ldots, k_{q} \quad\left\{1, \ldots, m_{j}\right\}$

Sales maximization is given if,

$\left|M V_{O_{i, j, k_{1},} C_{1}}\right|+\left|M V_{O_{i, j, k_{2}, C_{2}}}\right|+\ldots+\left|M V_{O_{i, j, k_{q}, c_{q}}}\right|=m_{j} \mid c_{1} \quad c_{2} \quad \ldots \quad c_{q} ; k_{1}, k_{2}, \ldots, k_{q} \quad\left\{1, \ldots, m_{j}\right\} \quad(10)$

\section{Sale Moment discussion}

The traditional $S M$ is characterized by having a personal relationship. Some factors that cause that $C$ generates an $S M$ are 1) routes, 2) rides, and 3) searches.

1. Route is when $C$ makes a necessary displacement through exhibition places of $P$.

2. Ride, $C$ is directed to exhibition place of $P$ in order to get a distraction.

3. Search refers to fact that $C$ assists to the exhibition place to find $P_{j}$ that must have desirable characteristics, Figure 4.

The $S M$ is due to factors combination, where one of them makes the fact. Since $P$ is handicrafts, it is unlikely that the $S M$ is caused by search of an $O$ particular. This fact denotes that $S M$ is an occasional event and requires to be analyzed in order to get $|S M| 0$ because this represents sales (Stanton, Etzel, \& Walker, 2007). When $C$ goes through the showplace of $P$, there is an implicit offer of $P$ that is manifested with physical $O$. It may also be the case that the offer is made verbally. An unlikely event occurs when a catalog of $P$ is used (Parra Paz \& Madero Vega, 2005). In any case, the P evaluation is accentuates with dialogue. Needless to say that exist a risk where the dialogue could make that $\mathrm{P}$ is rejected or vice versa. 
Figure 4. Buyers in Sales Moment.

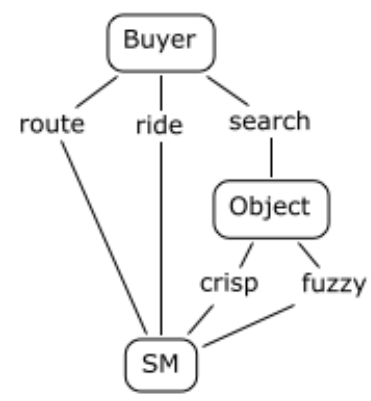

Source: Own source.

Whether the offer is given by physical $P$ or if it is by physical catalog, $C$ is stimulated by factors as, a) sound, b) smell, c) pleasant to touch, d) image, e) price and / or e) attention received (Parra Paz \& Madero Vega, 2005), Figure 6.A. Some factors are related directly with $P$ attributes such as: sound, smell, touch and image. The image implicates size, color and shape. The price is an indirect attribute since it does not specify a physical part of $P$. The care factor to get $|S M| 0$ is not always obvious and is dynamic because of its temporality and changes between different $S M$ and during the same $S M$. Some of stimulus factors could have a decisive participation to cause the desired effect in $C$ and others could not have participation without this being inconvenient for the generalization proposed. For example, the sound is not involved in a painting to stimulate the desire. In the case that the offer of $\mathrm{P}$ be from physical catalog, the direct factor associated with $P$ is the image and is known that this describes $P$ with limitations. In this case, the factors of smell, touch and / or sound are attributes of $P$ associated with the catalog characteristics and therefore are so important to take care with this medium (Prieto Herrera, 2005). The price of $P$ is given visually and / or verbally and this is associated with attention factor. To stimulate the desire efficiently, is recommendable that the factors are well differentiated. The seduction of $C$ (evaluation moment) is given when factors generate the effect of desire because it means that a purchase intention is present (Parra Paz \& Madero Vega, 2005). The next critical moment is when going to negotiation of quantity, price and / or delivery of $P$. Satisfied the concerns that validate the opportunity and good taste of $C$, it can complete the purchase attending last negotiation moment. Depending of $O$ number the price is accorded. Delivery can be immediately or later. When delivery is later then the parts must make a negotiation of shipping cost and / or shipping method and / or delivery time. Having overcome the 
moments of evaluation and negotiation, the purchase is materialize and than the process pass to the period of post-purchase where again the $C$ evaluates other characteristics associated with $P$ as a) received treatment, b) $P$ durability and c) $P$ taste. It is highly recommended to take care with $S M$ process in last stage, because the recommendation generates an upward or downward spiral in $S M$ 's reproduction, Figure 5.

Recapitulating, it has to

1. The $C$ makes an assessment about the $P$ throughout the $S M$.

2. $P$ attributes are natural factors to influence the decision of $C$.

3. $P$ offered through a physical catalog has limitations because this increases $C$ 's doubts about $P$.

4. There are three events that must be overcome in order that $C$ buys something.

- When $C$ is stimulated by natural attributes of $P$, for example the image.

- When $P$ 's associated attributes are negotiated, for example the price.

- When attributes of $P$ 's associated attributes are negotiating, for example the shipping.

5. The events are in order of importance as them are mentioned.

6. It is desirable that $M S$ ends with a purchase and a subsequent recommendation or a purchase only.

\section{Virtual Sale Moment}

The use of ICT is the way to increase the SM because encourages to reproduce it virtually due to the answer of the problem has much more that add than another form of offer is the way to increase the $S M$ because encourage to reproduce $S M$ in virtually due to the answer of problem has much more that add than another form of offer, Figure 6. B. This is justified if it is accepted that ICT expose a parallel reality experience. Physical and virtual SM have disadvantages and advantages that will be presented later. So, a virtual catalog is used to offer $P$ where the image is the direct attribute associated of $P$ that stimulates $C$ desire. Simplicity of site, connection speed, price and attention are indirect attributes of $P$ (Fontalvo, 2013). The simplicity and speed are attributes that are present in both $S M$ types, 
but in virtual SM is evident. Some of these factors are essential to overcome the evaluation moment. For example, the involvement of attention is not necessary, if it is been maintained other factors. There are studies that say the importance to has a website with access simple and fast, (López Cortés, Morales Hernández, \& Vega Chacón, 2011). After that evaluation moment has been overcome, as in case of the Physicist SM, the process is passed to negotiationl moment. In this moment is negotiated quantity, price and delivery. Delivery involves subtopics that must be discussed in other moment called negotiation 2 moment. The particularity of negotiations in the virtual world is that they are given automatically, where the $C$ fed amounts of $O$ to the system and receives the associated shipping costs and delivery time. Note that in physical SM the information of delivery time is given implicitly with the shipping, where the $C$ itself collects his purchase. The post-purchase period is similar as the physical SM. It emphasizes that care must be taken in the evolution of the virtual $S M$ because, unlike physical $S M$, the interrelation with $C$ is limited and a failure is criticized severely. Unlike the physical SM, the virtual SM is articulated strongly with actions of other actors for example, messaging, WEB support, domain use, order handling, banks, etc. It is clear to see that the SMEpott could lose the direct $S M$ control therefore it should anticipating to problems for example the supply of $P$, and take care the terms of the relationship with other actors.

Figure 5. The Sale Moment and its transactional evolution.

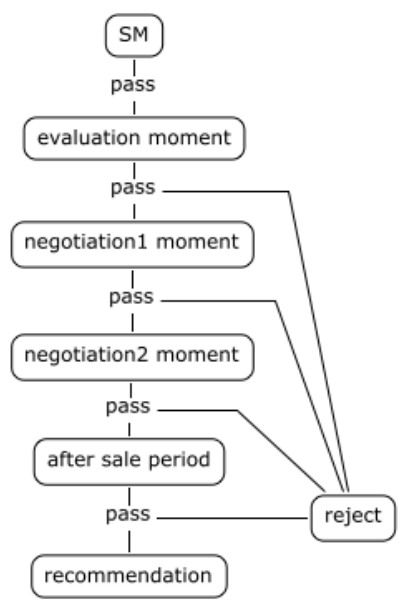

Source: Own source. 
Figure 6. Moment of physical and virtual sale.
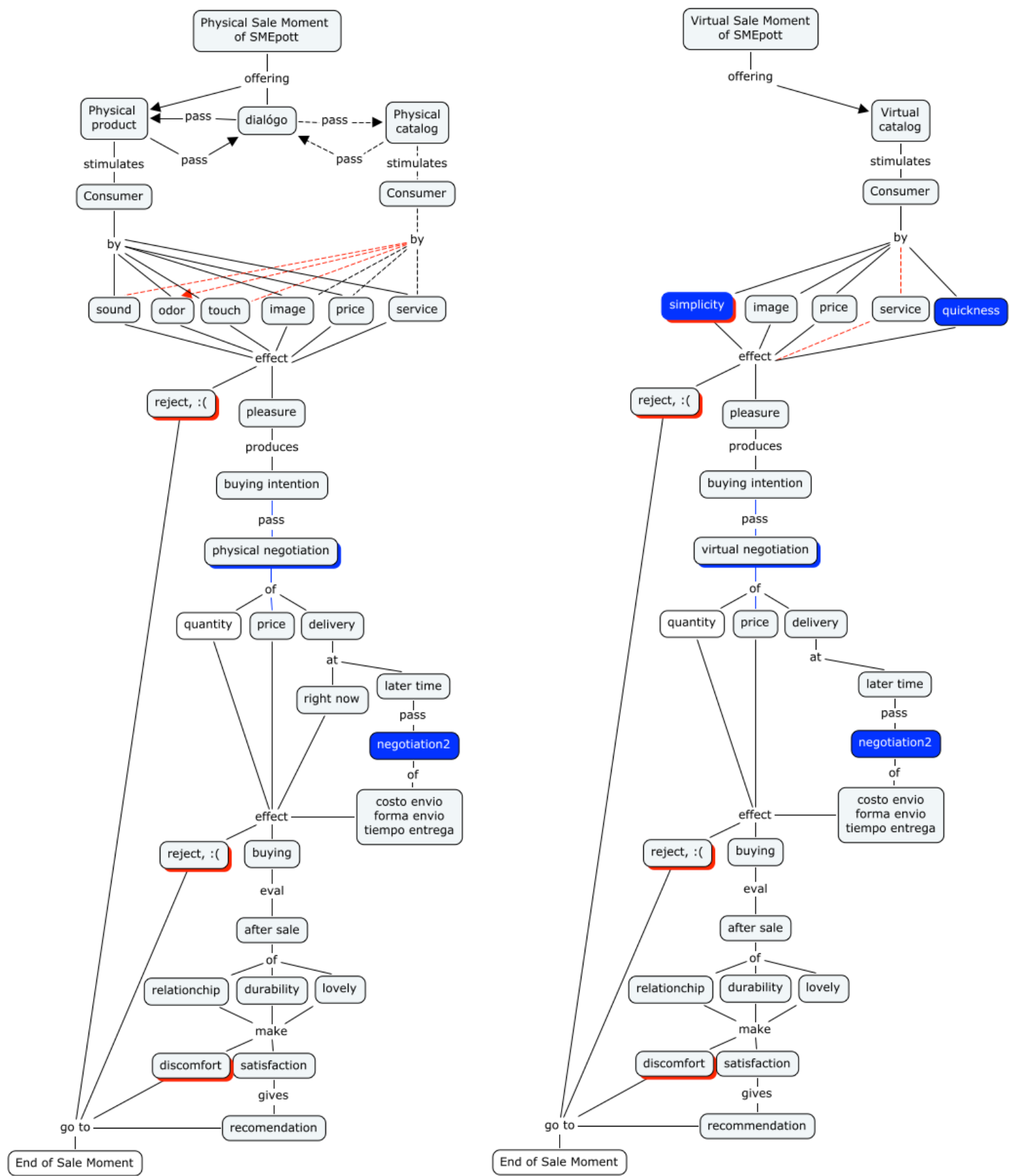

Source: Own source. 


\section{Physical Vs virtual sale moment}

Many papers deal with advantage and disadvantages of different form of business as (Fernández Portillo, Sánchez Escobedo, Jiménez Naranjo, \& Hernández Mogollón, 2015). Now, a particular points that are relevant will be shown.

Table 1. Advantages and disadvantages of physical and virtual SM.

\begin{tabular}{|c|c|c|}
\hline & Advantages & Disadvantages \\
\hline Physical SM & $\begin{array}{l}\text { - The senses are stimulated directly } \\
\text { - The negotiation is immediately and } \\
\text { the drawbacks are quickly attended. } \\
\text { - It common that } P \text { is gotten } \\
\text { immediately, or a tentative schedule is } \\
\text { made for the delivery or shipping. } \\
\text { - Easy Logistics } \\
\text { - Shared responsibility }\end{array}$ & $\begin{array}{l}\text { - It serves in sequence } \\
\text { - A person is indispensable to attend } \\
\text { the customers } \\
\text { - Transactions are in cash mostly } \\
\text { - Occasional customers }\end{array}$ \\
\hline Virtual SM & $\begin{array}{l}\text { - It can meet in parallel } \\
\text { - The retail outlet extension } \\
\text { - SM needs a clarifier of doubts only } \\
\text { - The opportunity of international sales } \\
\text { is increased } \\
\text { - Money management in digital form } \\
\text { - Sales control is increased } \\
\text { - Manage client list } \\
\text { - The feedback positive is good } \\
\text { - Improved inventory control }\end{array}$ & $\begin{array}{l}\text { - Very elaborate logistics } \\
\text { - The responsibility is emphasized in } \\
\text { the Seller } \\
\text { - The SM has dependence of other } \\
\text { actors as the website, shipping } \\
\text { office, banks, etc. } \\
\text { - Improved inventory control } \\
\text { - The website information to reliably } \\
\text { recreate the } P \text { must be caring } \\
\text { - The feedback negative is bad } \\
\text { - It is limited the stimulation of } \\
\text { senses }\end{array}$ \\
\hline
\end{tabular}

Source: Own source.

\section{WEB portal proposal}

As discussed above, the virtual $S M$ is a replica of physical $S M$ and must meet certain characteristics to stimulate the $C$ adequately.

Feature1: The portal should have a picture of $P$ as would a sideboard and when hovering the cursor over $P$ image it becomes enlarged and offer details such as size, weight, material, design and choice of spending to cart shopping where the number of desired objects are specified also. 
Feature2: If it needs more than one image to display all $P$ then it can put a door image to access another page (room) with more $P$.

Feature3: In the case that the portal will serve to promote more than one SMEpott then it would be appropriate to put pictures alluding to each so that the user properly select your preference.

Feature4: Chat option.

Feature5: Service feedback.

Feature6: The payments must be electronic but it need attend the customers in all moment.

\section{Conclusions}

The previous exposition shows that non-trivial logistics elements have to be solved and perhaps this makes that SMEpotts in Jalisco do not use a WEB portal to market, but also was argument that TICs use it is the necessary step to trade. There has been a conceptual discussion of terms used in the analysis of the process of physical buying-selling, which is used traditionally by SMEpott. It discussed the similarity reason between physical and virtual process. Virtual SM is an undeniable way to grow the business and / or to stay in the marketplace and / or to be prepared for the changes that the market demands. Finally, a proposal of portal WEB is made. This portal has features that were showed in this work. 


\section{Bibliography}

Aguilera Enríquez, L., González Adame, M., \& Rodríguez Camacho, R. (2011). Estrategias Empresariales para la Competitividad y el Crecimiento de las Pymes. Una Evidencia Empírica. Investigación y Ciencia de la Universidad Autónoma de Aguascalientes (53), 39-48.

Alburquerque, F. (Ago de 2004). Sistemas Productivos Locales: Una Mirada desde la Política Económica Local para la Generación de Empleo. (S. CEPAL-MTEySS, Ed.) OIT Argentina , 1-10.

Algieri, M. A. (2007). Alternativas de Financiamiento para la Pequeña y Mediana Empresa (PYME) de las Industrias Metálicas y Metalmecánicas en Barquisimeto,Estado Lara. Tesis Maestría, Universidad Centroccidental "Lisandro Alvarado, Decanato de Administración y Contaduría, Barquisimeto.

Anaya Tejero, J. J. (2015). Logística y Distribución. El Transporte de Mercancías. Enfoque Lógistico de la Distribución. Pozuelo de Alarcón, Madrid, España: ESIC.

Belloch, C. (2012). Las Tecnologías de la Información y Comunicación en el Aprendizaje. Recuperado el 25 de Sep de 2016, de http://www.uv.es/bellochc/pedagogia/EVA1.pdf

Briozzo, A., Vigier, H., Castillo, N., Pesce, G., \& Speroni, M. C. (2016). Decisiones de Financiamiento en Pymes: Existen diferencias en función del tamaño y la forma legal? Estudios Gerenciales, 32, 71-78.

Calvo Marín, D. C., \& Ospina Ospina, D. H. (2014). Jóvenes y TIC: una mirada desde la vida cotidiana. 90 textos y sentidos (9).

Fernández Portillo, A., Sánchez Escobedo, M. C., Jiménez Naranjo, H. V., \& Hernández Mogollón, R. (2015). La Importancia de la Innovación en el Comercio Electrónico. Universia Business Review . 
Fontalvo, S. I. (2013). El Comercio Electrónico como Recurso de Competitividad para las PYMEs de la Sierra Nevada de Santa Marta. Revista Gestión de las Personas y Tecnología (17).

González García, F. M. (2008). El Mapa Conceptual y el Diagrama V. Recursos para la Enseñanza Superior en el Siglo XXI. Madrid, España: NARCEA, S.A. de Ediciones.

Gómez Sánchez, C. M., \& Dorantes Escamilla, V. M. (2006). Tecnologías de Información en las Pequeñas y Medianas Empresas (PYMEs). Tesis de grado, Universidad Nacional Autónoma de México, Facultad de Estudios Superiores Aragón, San Juan de Aragón.

INEGI. (2009). Micro, pequeña y gran empresa. Estratificación de los establecimientos. Ags: Instituto Nacional de Estadística y Geografía.

Hernández Gutiérrez, V. H., \& Reta Martínez, M. Á. (2011). Las Estrategias de Venta por Internet para las PYMEs de Servicios en México: Perfil de Propietarios e Ingresos. Tesis maestría, Universidad Nacional Autónoma de México, Facultad de Contaduría y Adminstración, D.F.

Jalisco, G. d. (2016). Monitoreo de Indicadores del Desarrollo de Jalisco. Recuperado el 08 de Nov de 2016, de seplan.app.jalisco.gob.mx: https://seplan.app.jalisco.gob.mx/mide/valorIndicador/listaMunicipalCiudadana/108 9? agregado $=1 \&$ temaElementalId $=9 \&$ nivelId $=\& \max =10 \&$ programaId $=\&$ conceptoId $=\&$ ids $=\&$ nivelIndicadorId=\&url=buscar\&temaId=\&palabra $=\&$ offset=10\&dependen ciaId $=\&$ dimension $I d=\&$ controlador $=$ indicador $\&$ accion $=$ consultarDatos\#final

Luna Huertas, P., Ruiz del Castillo, J. C., \& López Jiménez, D. (2012). Nuevos Paradigmas para las Empresas en la era Tecnológica: La Socialización de las PYMEs. Ciencias Económicas , 30 (1), 147-162.

Llamas Aréchiga, B., González Aboytia, M. A., Vásquez Duarte, J. F., Siari Valenzuela, D. G., Valenzuela Hernández, I. V., \& Silva Hernández, A. C. (2014). Elementos que 
Promueven Competitividad en las PYMEs, un estudio regional. Revista de Investigación Académica sin Frontera (19).

López Cortés, E. A., Morales Hernández, H. M., \& Vega Chacón, J. (2011). Desarrollo de una Aplicación WEB para Comercio Electrónico enfocada a PYMEs. Instituto Politecnico Nacional, Escuela Superior de Ingeniería Mecánica y Eléctrica. IPN.

Mochón, F. (2006). Principios de Económia (3ra edición ed.). Madrid, España: Mc Graw Hill.

Montoya del Corte, J., Martínez García, F. J., \& Somohano Rodríguez, F. M. (Jul-Dic de 2013). Análisis Estratégico para el Desarrollo de las PYMEs en Cantabria, España. (22) , 8-26. Sotavento M.B.A.

Parra Paz, E. d., \& Madero Vega, M. d. (2005). Estrategias de Ventas y Negociación con Técnicas de Programación Neurolingüisticas (PNL) y Tecnología Colinde (2a edición ed.). D.F., México: Panorama Editorial.

Prieto Herrera, J. E. (2005). Las Ventas: Una Profesión para Gente Superior (3ra edición ed.). Bogotá, Colombia: ECOE Ediciones.

Saavedra García, M. L., \& Tapia Sánchez, B. (2013). El uso de las Tecnologías de la Información y Comunicación TIC en las micro, pequeñas y medianas empresas (MIPyME) industriales mexicanas. Enl@ce Revista Venezolana de la Información Tecnología y Conocimiento , 10 (1), 85-104.

Stanton, W. J., Etzel, M. J., \& Walker, B. J. (2007). Fundamentos de Marketing (14th edición ed.). México: Mc Graw Hill.

Reyes Nodhal, R. E., Alvarado Castellanos, T. d., \& Marcelo Guevara, E. (2013). La Industria en los Municipios de Guadalajara, Zapopan, Tlaquepaque y Tonalá. Expresión Económica (31). 
Tello, E. (2007). Las Tecnologías de la Información y Comunicaciones (TIC) y la Brecha Digital: Su Impacto en la Sociedad de México. Revista de Universidad y Sociedad del Conocimiento , 4 (2). 